\title{
Lenticulostriate-medullary artery anastomoses in moyamoya disease
}

\author{
Hyun-Ji Cho, MD; Dong Beom Song, MD; Hye-Yeon Choi, MD; and \\ Ji Hoe Heo, MD, PhD
}

The development of extensive collaterals is a characteristic feature of moyamoya disease. They include basal collaterals, which are composed of lenticulostriate and thalamoperforate arteries, leptomeningeal collaterals from the posterior cerebral arteries, and transdural collaterals from the external cerebral arteries. ${ }^{1}$ In a normal brain, the ends of the len- ticulostriate and medullary arteries of the middle cerebral artery are not connected. Although anastomoses between these two arteries may develop in moyamoya disease, typical angiographic findings are rarely reported. ${ }^{2} \mathrm{We}$ present angiography findings (figure) in a 57-year-old woman with moyamoya disease who presented with intermittent weakness in her left arm and showed lenticulostriate-medullary artery anastomoses.

\section{References}

1. Lee JY, Kim KS, Song SK, Ahn SH, Nam HS, Heo JH. Atypical territorial infarction in moyamoya disease. Neurology 2005;65:E28.

2. Takahashi M. Magnification angiography in moyamoya disease: new observations on collateral vessels. Radiology 1980;136:379-386.

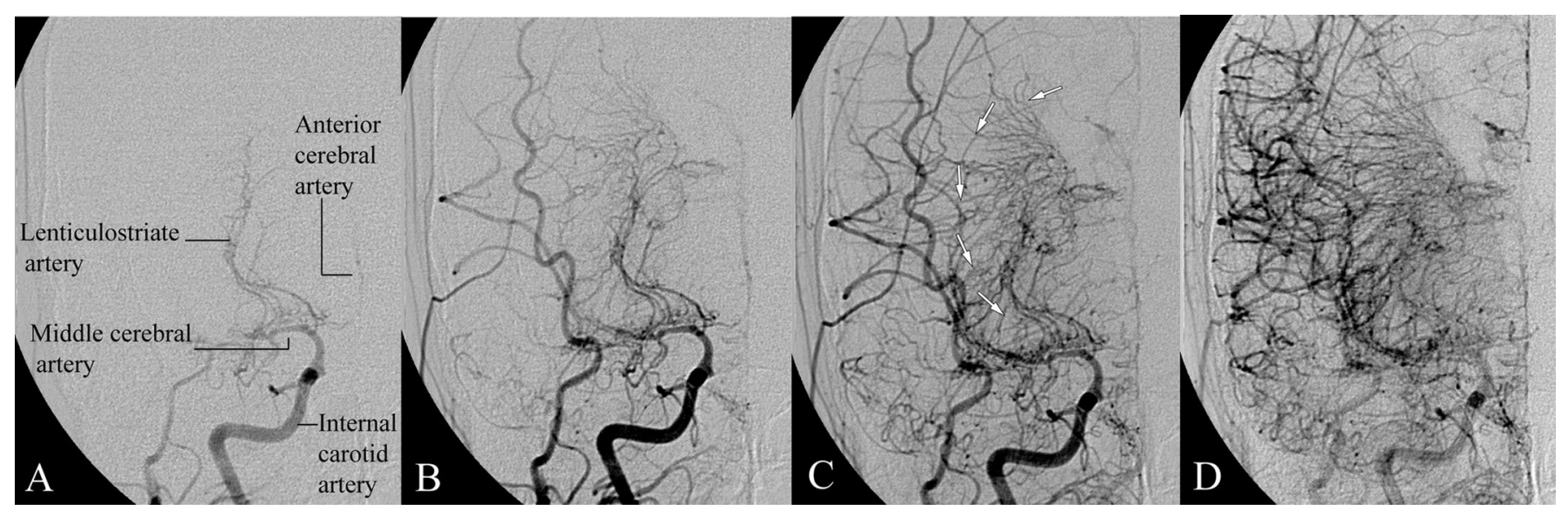

Figure. Sequencing of the right carotid anteroposterior angiograms from initial (A) to early (B), mid (C), and late (D) arterial filling. It shows steno-occlusion of the anterior and middle cerebral arteries. Fine vascular networks (arrows) from the lenticulostriate arteries anastomose with medullary arteries, which eventually reconstitute the middle cerebral artery.

From the Department of Neurology, Yonsei University College of Medicine, Seoul, Korea.

Supported by a grant from the Korea Health 21 Research and Development Project, Ministry of Health \& Welfare, Republic of Korea (A060272).

Disclosure: The authors report no conflicts of interest.

Received September 21, 2006. Accepted in final form November 30, 2006.

Address correspondence and reprint requests to Dr. Ji Hoe Heo, Department of Neurology, Yonsei University College of Medicine, 134 Shinchon-dong, Seodaemoon-gu, 120-752, Seoul, Korea; e-mail: jhheo@yumc.yonsei.ac.kr 


\section{Neurology}

\section{Lenticulostriate-medullary artery anastomoses in moyamoya disease Hyun-Ji Cho, Dong Beom Song, Hye-Yeon Choi, et al. \\ Neurology 2007;68;E21 \\ DOI 10.1212/01.wnl.0000259084.38361.f2}

This information is current as of April 9, 2007

\section{Updated Information \& Services}

References

Citations

Subspecialty Collections

Permissions \& Licensing

Reprints including high resolution figures, can be found at: http://n.neurology.org/content/68/15/E21.full

This article cites 2 articles, 1 of which you can access for free at: http://n.neurology.org/content/68/15/E21.full\#ref-list-1

This article has been cited by 2 HighWire-hosted articles: http://n.neurology.org/content/68/15/E21.full\#\#otherarticles

This article, along with others on similar topics, appears in the following collection(s):

\section{All Cerebrovascular disease/Stroke}

http://n.neurology.org/cgi/collection/all_cerebrovascular_disease_strok e

Childhood stroke

http://n.neurology.org/cgi/collection/childhood_stroke

Infarction

http://n.neurology.org/cgi/collection/infarction

Information about reproducing this article in parts (figures,tables) or in its entirety can be found online at:

http://www.neurology.org/about/about_the_journal\#permissions

Information about ordering reprints can be found online:

http://n.neurology.org/subscribers/advertise

Neurology ${ }^{\circledR}$ is the official journal of the American Academy of Neurology. Published continuously since 1951, it is now a weekly with 48 issues per year. Copyright. All rights reserved. Print ISSN: 0028-3878. Online ISSN: 1526-632X.

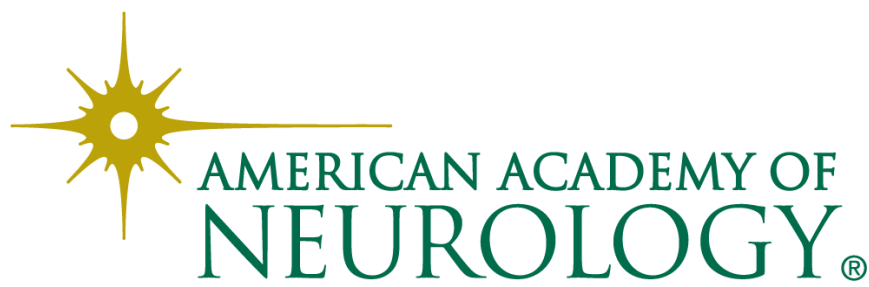

